\title{
An Integrated Hydrological Model for Water Balance Estimation in the Chirchik River Basin, Northern Uzbekistan
}

\author{
Saidislomkhon Usmanov, Yasuhiro Mitani, Tetsuya Kusuda \\ Department of Civil Engineering, Graduate School of Engineering, Kyushu University, Fukuoka, Japan \\ Email: said@doc.kyushu-u.ac.jp, mitani@doc.kyushu-u.ac.jp, hai54900@par.odn.ne.jp
}

Received 21 March 2016; accepted 9 July 2016; published 12 July 2016

Copyright (C) 2016 by authors and Scientific Research Publishing Inc.

This work is licensed under the Creative Commons Attribution International License (CC BY).

http://creativecommons.org/licenses/by/4.0/

(c) (†) Open Access

\section{Abstract}

Accurate and detailed information of hydrological balance, and its dynamic nature is needed to develop strategies for sustainable use and management of water resources. In this concern, a fully integrated MIKE SHE model was developed to study the hydrological balance of the Chirchik River Basin, Uzbekistan. Parameters in the model were calibrated and simulated results were validated for the periods 2009-2011 and 2012-2013 in term of two observed hydrological parameters: streamflow rate and groundwater table. After the successful calibration of the parameters, the model produced quantitative results of the water cycle and provided better understanding of the surface and groundwater interactions. The results show that the hydrological balance is strongly dependent on the intensity of agricultural activity within the basin. An actual evapotranspiration was found as a main water loss element among the water transport components due to large-scale agricultural irrigation activities. This corresponds to $\mathbf{7 7 \%}$ of the total water budget as an average. A satisfactory water balance simulation error was obtained after adjusting model parameters to basin environment.

\section{Keywords}

Integrated Model, MIKE SHE, MIKE 11, Hydrological Balance Component

\section{Introduction}

The Republic of Uzbekistan is a doubly land locked country in central Asia. Therefore, most water resources are supplied from neighboring countries. In the last decades, water supply into to the country has significantly de-

How to cite this paper: Usmanov, S., Mitani, Y. and Kusuda, T. (2016) An Integrated Hydrological Model for Water Balance Estimation in the Chirchik River Basin, Northern Uzbekistan. Computational Water, Energy, and Environmental Engineering, 5, 87-97. http://dx.doi.org/10.4236/cweee.2016.53009 
creased due to the mismanagement of transboundary water resources by Central Asian countries ([1]-[3]). Consequently, most river basins in the region suffer from water shortages and increased aridity. Global climate change threatens to worsen these life-threatening problems [4]. The development of plans for the sustainable usage of water resources, and mitigation and adaptation strategies is a key concern for all stakeholders across Uzbekistan [5]. The Chirchik River Basin (CRB) is considered one of the country's largest and most important basins. It is located in the northeastern province of Tashkent (Figure 1), and its economy relies heavily on agricultural production; employing most of the region's population and consuming the lion share of available water through irrigation practices [6]. Unsurprising, the CRB is facing several potentially severe water related problems, including increased aridity and, land salinization, and has been declining in agricultural production. Continuously, rising groundwater level and the inefficient use of river waters are assumed to further cause these problems [5].

Poor management of water resources due to limited knowledge of hydrological processes has been identified as a root cause of water resource problems in the basin ([7] [8]). Efficient management requires accurate estimation and modeling of water balance and main hydrological parameters. In order to obtain useful results, irrigation processes, which play an important role in the hydrological cycle, should be included in the model to account for the contribution of irrigation water to other hydrological parameters. MIKE SHE coupled fully distributed hydrological models have been used widely and effectively by many researchers in producing detailed water balance estimations, examining hydrological responses to land use and cover change, and in groundwater and irrigation management ([9]-[12]). Compared with other conventional methods, the model used in this study has the advantage of fully integrating the surface, subsurface, channel flow and their interactions in hydrological process simulation.

Moreover, this model also has an integrated system to calculate irrigation processes [13]. Further evaluation and comparison of the MIKE SHE and other hydrological models are provided by ([14]-[17]). Integrated models have rarely been used in CRB studies, and there is a paucity of literature estimating water balance and hydrological parameters. In this concern, a main aim of this work is to study hydrological processes in the basin territory through detailed water balance estimation using an integrated hydrological model. This research aims to contribute to the knowledge of groundwater and surface water interaction and spatial variability of hydrological parameters.

\section{Method and Materials}

\subsection{Study Area}

The CRB is located in the Tashkent province in the northeastern part of Uzbekistan and it covers almost one third of the province. The total area of the basin is $5626 \mathrm{~km}^{2}$, of which $1982 \mathrm{~km}^{2}$ is agricultural land. The topography varies from 237 to $4293 \mathrm{~m}$ above the mean sea level, and the area's population is around 2.1 million people. As shown in Figure 1, the CRB consists mainly of upper stream in the northeastern region, and downstream in southwestern part. The southwestern area is almost exclusively topographically plain. Therefore, the boundary of the basin in the upper stream is delineated according to watershed concepts, whereas the downstream is delineated according to the administrative boundaries of the districts of the Tashkent province. Overall, the basin's outer boundary only covers 10 districts out of 15 , including some parts of the Bostonliq district in the upstream site. The climate is a mix of arid and semi-arid. The climate of the upstream CRB is characterized by relatively high amounts of precipitation and lower average temperatures. The opposite climate characteristics are present in the downstream areas of the basin. Our previous study reveals that the potential evapotranspiration (PET) decreases from the downstream site (southwest) to the upstream site (northeast) as altitude increases [5]. Precipitation is around $810 \mathrm{~mm} /$ year in upstream sites, and approximately $426 \mathrm{~mm} /$ year in downstream areas. Rainfall increases $60 \mathrm{~mm} /$ year for every 100-meter increase in elevation due to orographic effects. Maximum snow storage depth can reach $1200 \mathrm{~mm} / \mathrm{year}$ in high mountainous areas [19]. The Chirchik River is formed by discharges from the Chravak water reservoir joining the Ugam River. This river supplies the main water resources for drinking and irrigation within the CRB. The capacity of Chravak reservoir is 2.1 billion $\mathrm{m}^{3}$, which is recharged by glaciers and precipitation. The Chirchik River is $161 \mathrm{~km}$ in total length and Ugam River is its main tributaries. The mean annual discharge of the Chirchik River is $200 \mathrm{~m}^{3} / \mathrm{s}$ with an annual flow of about $7.9 \mathrm{~km}^{3}$. Annually, the CRB uses on average 4.082 billion $\mathrm{m}^{3}$ water. More than $6 \%$ of this water is abstracted from deep aquifers with approximately $76 \%$ of this volume used for irrigation. The main agricultural crops of the basin are 


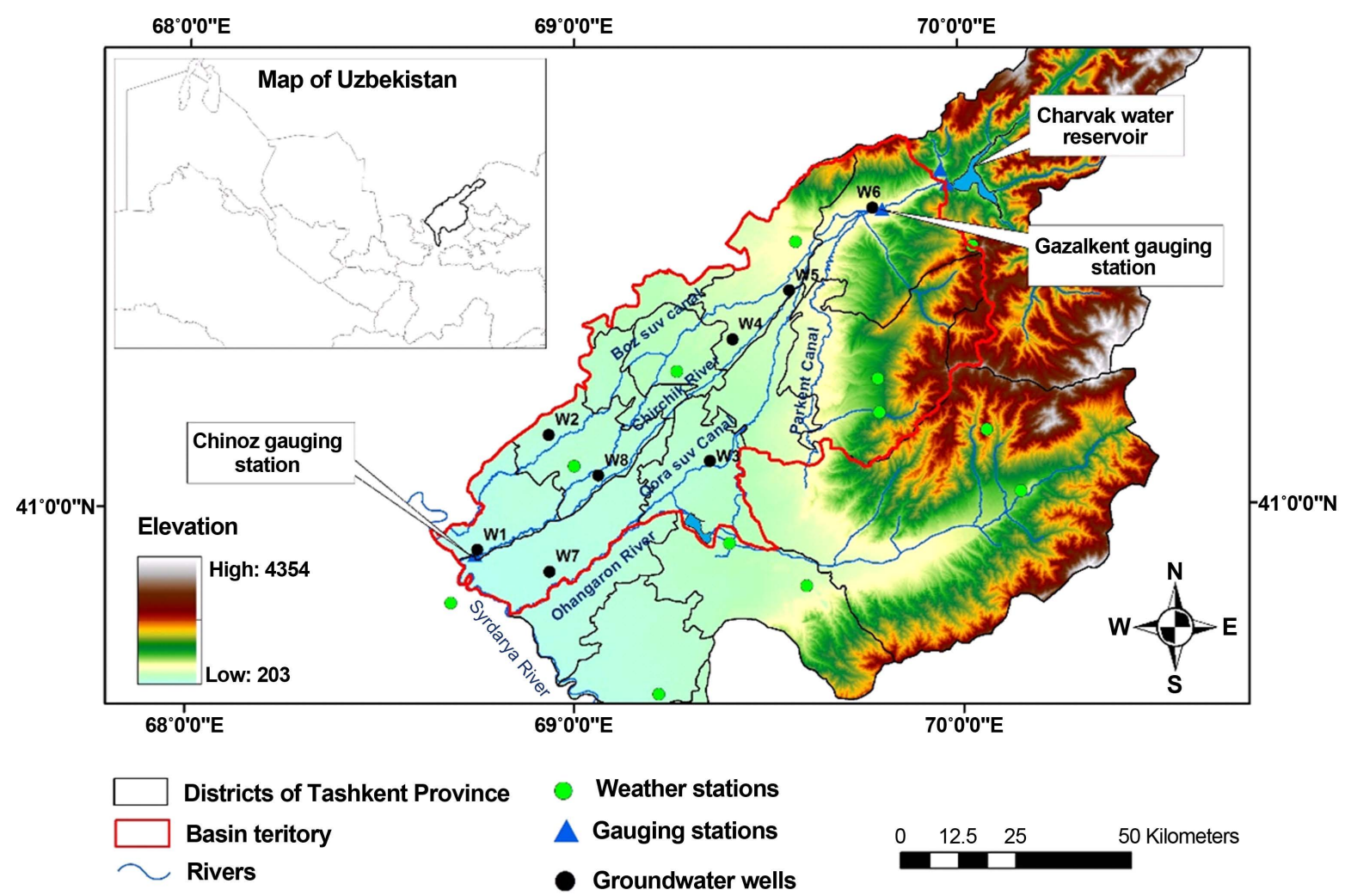

Figure 1. Tashkent province and the Chirchik river basin, Uzbekistan.

cotton and wheat. The largest expanse of irrigated land is located in the middle and downstream areas of the ba$\sin$ [4]. Chirchik River water is distributed to agricultural lands and urban areas via the Bozsuv, the Qorasuv and Parkent's main canals. The remaining volume is mixed with returned water from agricultural lands and urban areas, and discharged into the Syrdarya River.

\subsection{Model Construction}

The MIKE SHE model is a deterministic, fully distributed and physically based hydrological modeling tool. The model calculates the following major hydrologic process in the hydrological cycle by fully integrated basis: evapotranspiration, overland flow, unsaturated flow, saturated flow, and stream flow. MIKE SHE uses the MIKE 11 model to simulate stream flow, lakes, and channels in 1D. The model uses Kristen and Jensen method to calculate actual evapotranspiration (AET). This method requires leaf area index (LAI), and root depth (RD) parameters for each vegetation type. LAI is dimensionless quantity and defined the area of leaves per unit ground surface area $(\mathrm{LAI}=$ leaf area/ground area). Typical value of the LAI varies between 0 and 7 . The root depth is defined depth of roots in the roots zone of each vegetation type. This is used to estimate the amount of water extracted by the roots between the ground surface and the lover level of saturated zone. In MIKE SHE, the temporal variation of the LAI and RD must be specified for each vegetation types.

The Richard's 1D equation is used to calculate unsaturated flow process. The saturated flow component is calculated using the Darcy's 3D method. Also, snow melting and freezing processes are simulated using a degree-day empirical approach, which requires a degree-day coefficient of the study area. The MIKE 11 model uses a 1D Saint-Venant equation to compute stream flow computations. Finite element methods are used to solve these partial differential equations. MIKE SHE uses a network of regular grids to discretize the horizontal plane of a watershed, and represent the spatial variability of the calculated hydrological process. The model also simulates irrigation processes, pumping wells and various water control structures. Simulation of the irrigation processes requires irrigation command areas, water sources (rivers, wells or lakes), irrigation time and demand. The model simulates water releases from stream flow with these releases then converted to irrigation depth to 
over-irrigation area. A detailed explanation of MIKE SHE and MIKE11 hydrological models can be found in [13] and [20].

\subsection{Model Set Up}

The MIKE SHE hydrological model requires a spatially distributed data set, which includes topographical, soil, geological, land use, climate and initial potentiometric head data. These geospatial data were prepared with the ArcGIS 10.2 platform and converted to $500 \mathrm{~m}$ by $500 \mathrm{~m}$ grid format. All these geospatial data were projected to CRB's coordinate system (WGS84 UTM 42N). Surface topographical information was obtained from ASTER (Advanced Space borne Thermal Emission and Reflection Radiometer) GDEM (Global Digital Elevation Model). All data output time steps were set to 24 hours.

\subsection{Unsaturated Zone}

Unsaturated flow computation in the model requires a spatially distributed soil map, and its hydraulic parameters. The distributed soil map was obtained by digitizing 1:800,000 scale soil map of the Tashkent province. Soil types vary depending on geomorphological zoning in the basin. As total 12 soil types were identified in the basin region (Figure 2). This is a generalized soil map as it groups closely similar soil types as one. In this study Richards's equation was selected for calculating vertical flow in unsaturated zone, which are the functions of soil moisture retention curve and effective conductivity.

\subsection{Saturated Zone}

A 3D finite difference method was selected to compute saturated zone flow. This method requires the spatially distributed thickness of the computational geological layers. Only the surficial soil layer was considered in this research due to insufficient information of geological layers within the basin. Soil layer thickness was constructed using lithological information from a geological borehole dataset. The depth of the soil layer continuously increases from the mountainous to the downstream areas of the basin, ranging between $5-35$ meters. The assumption of soil-layer thickness is consistent within the geological literature [5]. Initial groundwater table data was generated through a geostatistical interpolation method using data from 90 groundwater wells. The specified groundwater table is used as the lower boundary condition for the unsaturated model.

\subsection{Land Use of the Basin}

A land use map of the CRB was obtained from AVNIR-2 (Advanced Visible Near Infrared Radiometer) satellite image through a supervised classification method using the Image Analysis toolset in ArcGIS 10.2. The primary land use data were calibrated with minor modifications performed using paper-based cadastral land use maps of districts in the Tashkent province. The land use of the basin has been classified as urban, water body, farmland, forest, grassland and arable lands (Figure 3). The values of seasonal changes of LAI and RD data were obtained from the Institute of Water Problems of Uzbekistan, and assigned to each land use class.

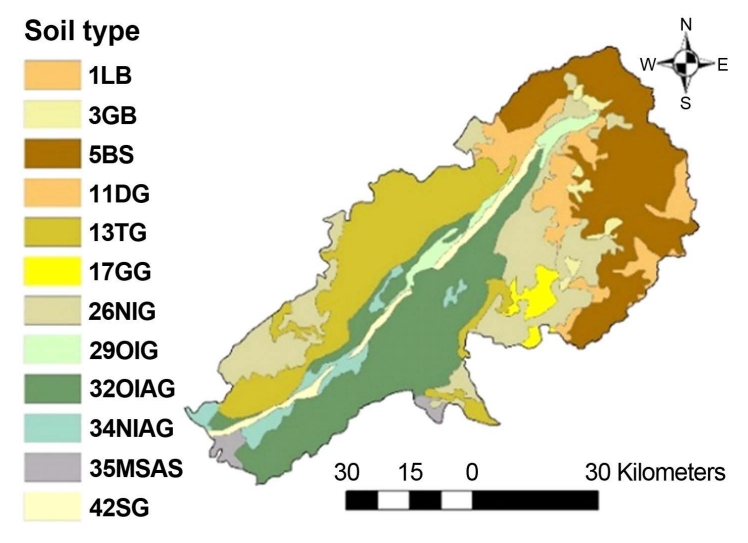

Figure 2. Soil map of the Chirchik river basin. 


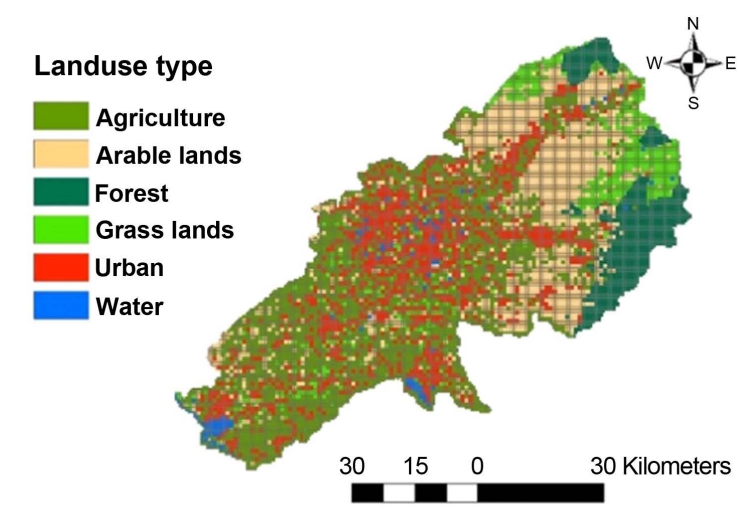

Figure 3. Land use map of the Chirchik river basin.

\subsection{Meteorological Input}

As shown in Figure 1, the CRB contains only eight weather stations. Climate data from each station was provided by the Uzhydrometeorological Authority of Uzbekistan. Potential evapotranspiration (PET) was calculated using the Penman-Monteih FAO 56 model [21]. The Thiessen polygon method was used to spatially distribute daily-accumulated precipitation, PET, the degree-day melting coefficient and short wave solar radiation data. Proper lapse rates were set to precipitation and temperature data for correction of the Thiessen polygon method in mountainous areas.

\subsection{MIKE 11 Model}

MIKE SHE uses the MIKE 11 model to simulate channel flow components. The MIKE 11 requires river network, cross section and discharge data of simulated streams. River and channel network data were extracted via digitization of the topographical map of the Tashkent province. Cross-section data were collected by field surveys in each of the simulated branches. Daily average discharge data of the Ugam River and the Charvak water reservoir were assigned to the upstream boundaries of the network. The created Chirchik stream network consists of four branches and 28 cross-section data. Storing frequency of simulation time step was set to $6 \mathrm{sec} 6 \mathrm{~min}$. The constant Manning's roughness coefficient was applied for each branch in the stream network. Time series data of water withdrawal rate of simulated rivers were set after coupling MIKE 11 flow simulation to the MIKE SHE model. After coupling MIKE 11, flow simulation to the MIKE SHE model irrigation area and demand were set to simulate irrigation processes. The model was set to obtain $100 \%$ of irrigation water from the Chirchik River.

\section{Results and Discussion}

Simulation results were calibrated and validated for 2009-2011 and 2012-2013 against stream flow and groundwater level data. Model performance was evaluated using mean error (ME), mean absolute error (MEA), root mean square error (RMSE), correlation coefficient $\left(\mathrm{R}^{2}\right)$ and the Nash and Sutcliffe coefficient (EF) [21]. Initially, climate parameters for modelling snow melting and freezing, including degree-day coefficient and maximum wet snow fraction, were adjusted to climatic conditions of the basin. The next step of calibration process focused on adjusting horizontal and vertical conductivity, and specific storage of saturated zone parameters.

\subsection{Stream Flow Hydrograph}

Table 1 presents performance statistics of streamflow simulation. Figure 4 and Figure 5 presents the comparison of simulated and observed discharges for the calibration and validation period in the Chinoz gauging station. The model was generally good, simulating daily streamflow discharge with an average of 0.91 (2009-2013) and 0.77 (2009-2013) of $\mathrm{R}^{2}$ and EF. The hydrographs show over and under estimation of streamflow discharge. Simulated river flow shows numerical imbalance when river water starts to be withdrawn for irrigation. This is clearly shown in March 2013 (validation period). Relatively high overestimation was detected from July to 
Table 1. The statistics of streamflow simulation at Chinoz gauging station.

\begin{tabular}{ccc}
\hline Statistical indicators & Calibration Period (2009-2011) & ValidationPeriod (2012-2013) \\
\hline ME & -42.87 & -28.36 \\
MAE & 53.83 & 32.92 \\
RMSE & 104.38 & 45.90 \\
$\mathrm{R}^{2}$ & 0.78 & 0.93 \\
EF & 0.22 & 0.76 \\
\hline
\end{tabular}

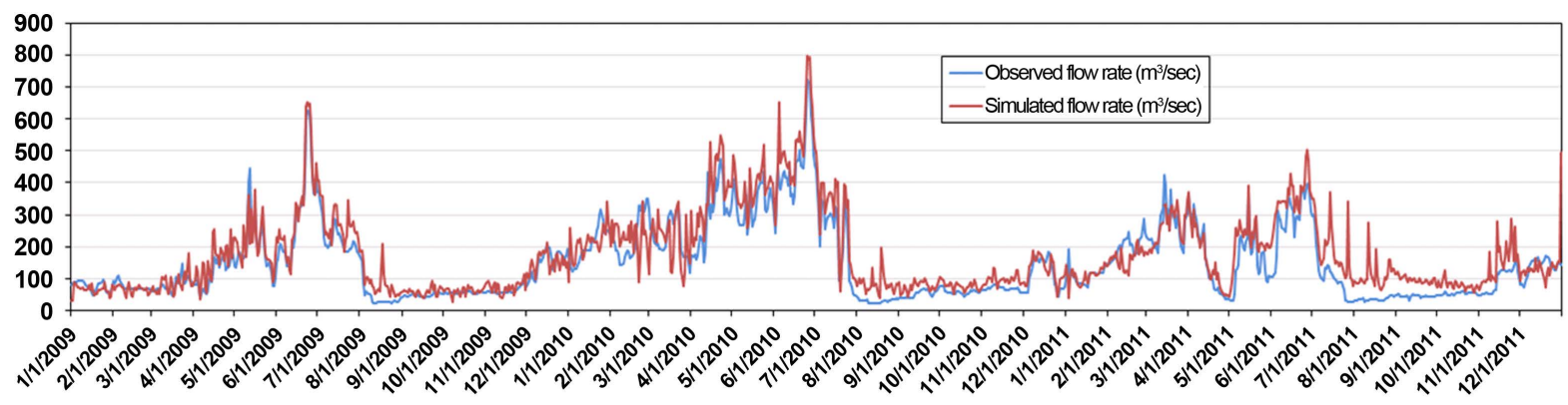

Figure 4. Observed and simulated streamflow in Chinoz gauging station (2009-2011).

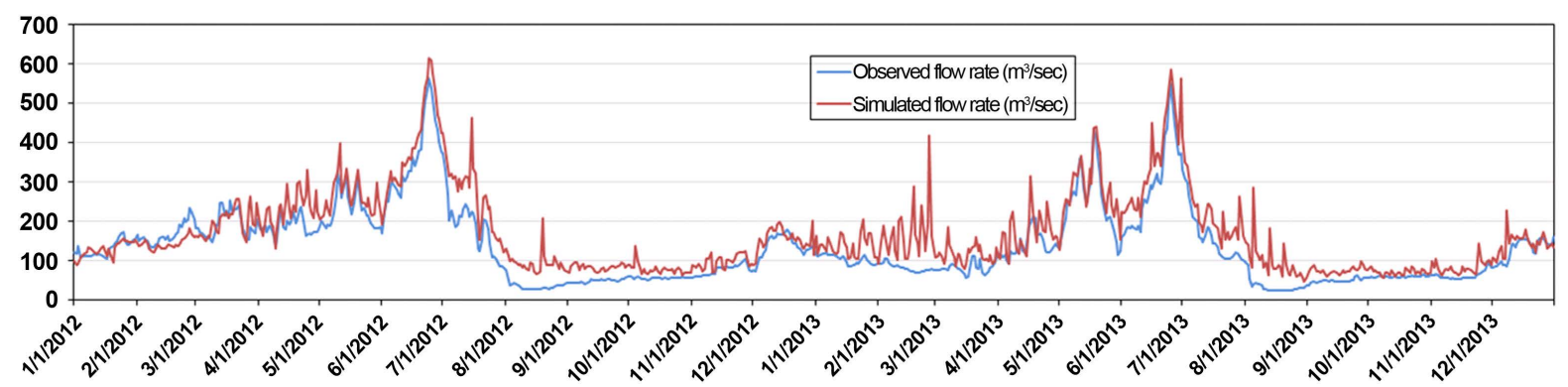

Figure 5. Observed and simulated streamflow in Chinoz gauging station (2012-2013).

November immediately after peak discharge rate. The main reason for this discrepancy is the absence of the operation information of small irrigation canals, reservoirs and hydro-engineering structures. Not accounting for the exchange between river water and saturated zone due to insufficient geologic data may also explain this.

\subsection{Groundwater Dynamics}

Simulations of groundwater level dynamics were calibrated and validated against average monthly observed well data for 2009-2011 and 2012-2013 respectively. In this study, data from a total of eight ground water wells was used.

These groundwater wells are located at up (W5, W6), middle (W4, W3) and downstream (W1, W2, W7 and W8) sites in the basin (Figure 1). The location of groundwater wells assists appraisal of model performance in different zones. The performance of groundwater simulations are provided in Table 2 and Table 3 . Figure 6 and Figure 7 show comparison of observed and simulated groundwater depth. Simulated groundwater dynamics show a satisfactory match with observed data at each location. Hydrographs show the groundwater table reaching its maximum level from April to May, and dropping to minimum levels at the end of September and October. In general, the model underestimated the groundwater level during peak recharge period. All hydrographs show consistent dependence on precipitation in terms of timing and quantity. Simulated groundwater elevations across the middle and downstream sites varied up to an average of $0.66 \mathrm{~m}$ during the study period in response to precipitation events. This value was equal to an average of $1.7 \mathrm{~m}$ in upstream sites. This shows that the fluctuation amplitude of the groundwater table in upstream sites is relatively higher. Potentiometric surface maps show the 
Table 2. Calibration results of groundwater simulation.

\begin{tabular}{cccccc}
\hline Groundwater well ID & ME & MAE & RMSE & R & EF \\
\hline W1 & 0.03 & 0.13 & 0.16 & 0.68 & 0.42 \\
W2 & -0.09 & 0.20 & 0.26 & 0.82 & 0.30 \\
W3 & 0.06 & 0.15 & 0.19 & 0.89 & 0.75 \\
W4 & -0.008 & 0.10 & 0.12 & 0.88 & 0.77 \\
W5 & 0.78 & 0.40 & 0.48 & 0.77 & 0.36 \\
W6 & 0.26 & 0.42 & 0.47 & 0.85 & 0.61 \\
W7 & 0.03 & 0.08 & 0.10 & 0.78 & 0.60 \\
W8 & 0.01 & 0.16 & 0.2 & &
\end{tabular}
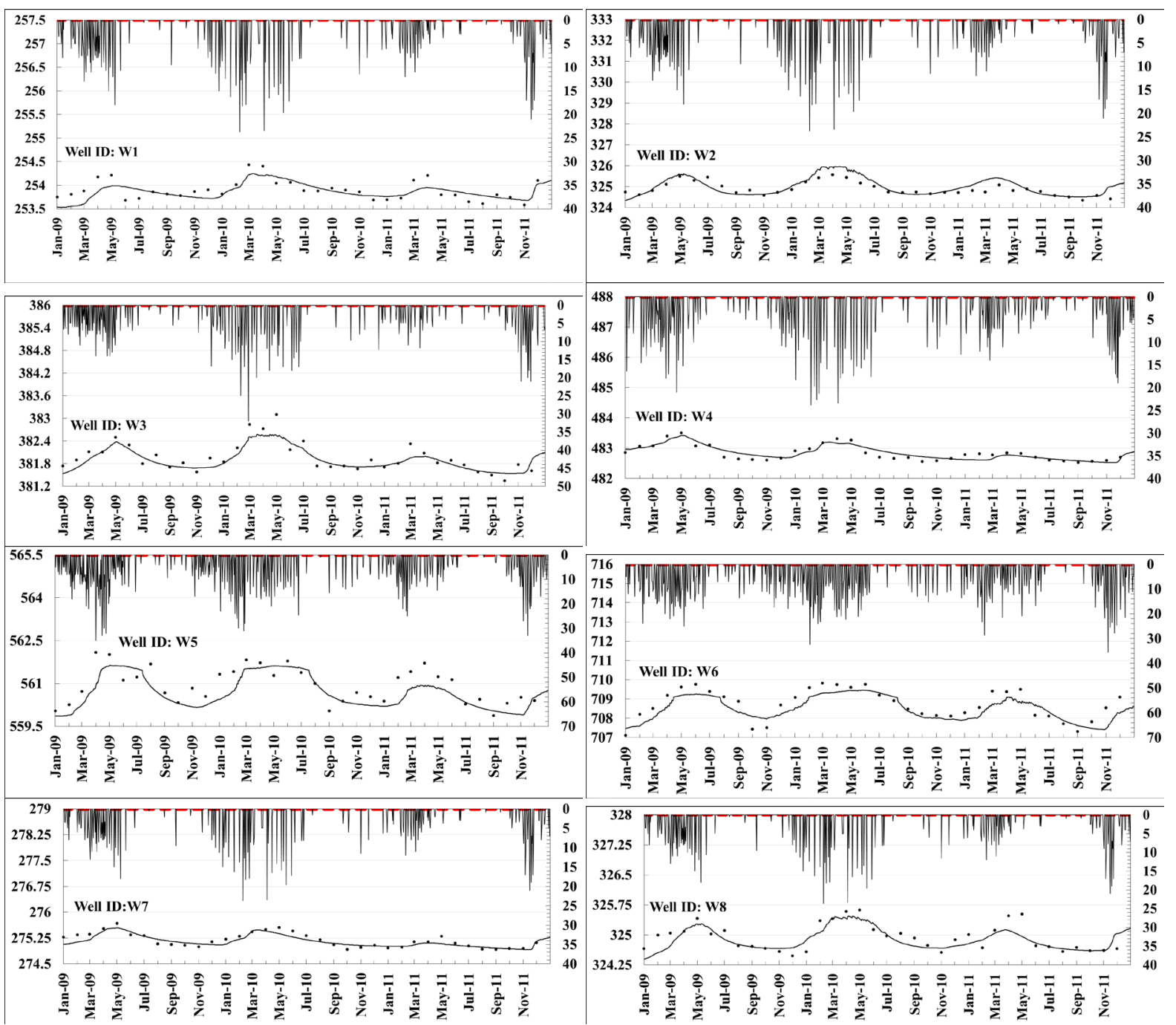

Figure 6. Observed and simulated groundwater depths in calibration period.

general direction of groundwater flows from Northeast to Southwest towards the Syrdarya River. This clearly underlines how groundwater flows contribute hugely to the Syrdarya River through base flows. This is an estimated average of $55 \mathrm{~mm} /$ year. 
Table 3. Validation results of groundwater simulation.

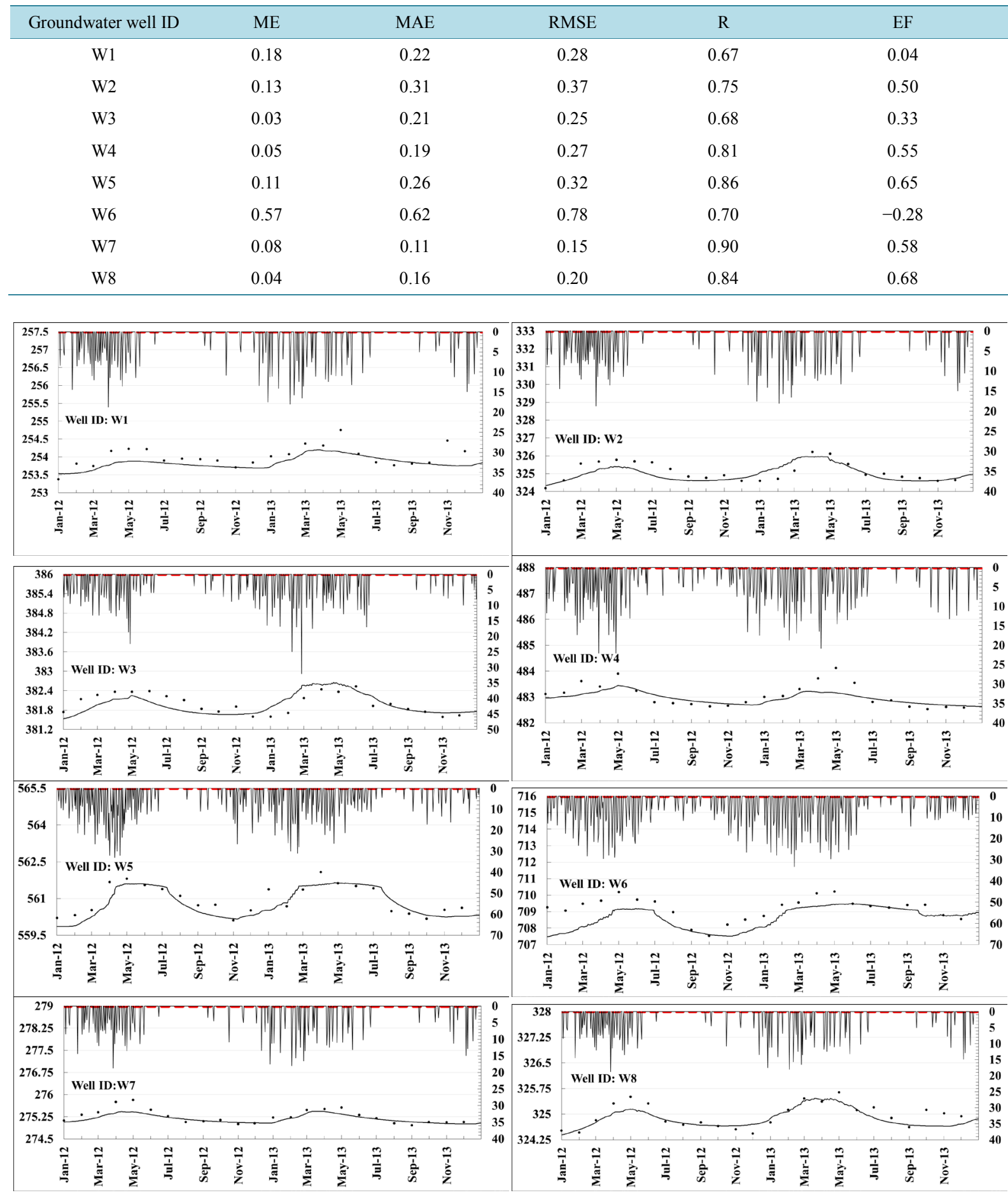

Figure 7. Observed and simulated groundwater depths in validation period.

\subsection{Water Balance}

The hydrological balance of the CRB is strongly dependent on agricultural activity and the climatic conditions of the basin. The model simulated the main hydrological processes, including evapotranspiration, overland unsaturated and saturated zone storage changes for calibration (2009-2011), and validation (2012-2013) periods. 
Table 4 shows the contribution of each water balance component in the CRB (mm/year). In simulation, precipitation and irrigation water are the main hydrological inputs to the water cycle. The overland water from snow and glacier melting is estimated at around $4 \%$ of the total inflow. The results indicate the main proportion of this water was lost through AET during the vegetation period (March-September) due to applied irrigation water.

The total AET was estimated at an average of $821 \mathrm{~mm} /$ year. This corresponds to $77 \%$ of the total water budget. The estimated average AET is exceeds around $8 \%$ from the average annual precipitation. The AET from snow surface was an estimated average of $89 \mathrm{~mm} /$ year or $10 \%$ of the total average AET. AET is highly variable across the watershed, and it predominantly increases in downstream sites in the basin. This occurs because PET increases with decreasing elevation [18]. The spatial range of AET is a varied average of $1211-692 \mathrm{~mm} /$ year. High AET (1211 mm/year) was estimated in downstream irrigation areas. This is almost two times greater than precipitation, and it occurs during non-rainy periods. The high evaporative power of the atmosphere is to be compensated by irrigation water.

It should be stated that decreased irrigation water causes of increased aridity in the basin. Simulation results show that the main recharge of groundwater is mainly provided by precipitation and irrigation water. During the study period, the total recharges varied from 180 to $221 \mathrm{~mm} /$ year (the last row in Table 4). This ranges from 17 to $20 \%$ of the total inflow. Groundwater recharge largely occurs from March to May (average $90-60 \mathrm{~mm} /$ month) when the amount of rainfall and snow melting increases in middle and downstream sites. In contrast, mountainous area recharge lasts until the end of June, and then starts to decrease, depending on variations in the amount of rainfall. A maximum recharge of $221 \mathrm{~mm} /$ year was estimated in 2010, when high amounts of precipitation occurred. The results indicate that in mountainous areas around $51 \%$ of total precipitation falls as a snow during the cold season. This proportion equaled an average of $29 \%$ in downstream sites. Snow storage mainly occurs from December to the end of February. Additionally, the results indicate overland flow peaks in mountainous areas of the basin in spring and fall with seasonal heavy rains and the beginning of snow melt on low infiltration ground surfaces. Snow pack melt-water contributed an average of $34 \%$ of the total overland flows. In this way, overland flow substantially feeds the source of the Chirchik River. This amount is an estimated average of $77 \mathrm{~mm} /$ year, which is $3 \%$ of the average total of precipitation. A small amount of water outflows from the basin boundary, particularly from downstream sites. This is an estimated average of $89 \mathrm{~mm} /$ year, or $4 \%$ of total precipitation. The overall water balance error was averaged at $2 \%$ and $3 \%$ during the calibration and validation periods. This shows incoming and outgoing water balance parameters were well satisfied.

\section{Conclusions}

The MIKE SHE integrated hydrological model was used to study the hydrological balance of the CRB. The

Table 4. Contribution of hydrological parameters to water balance.

\begin{tabular}{|c|c|c|c|c|c|c|c|}
\hline \multirow{3}{*}{$\begin{array}{l}\text { Hydrological } \\
\text { Parameter }\end{array}$} & \multicolumn{2}{|c|}{ Calibration } & \multicolumn{3}{|c|}{ Validation } & \multirow{2}{*}{ Average } & \multirow{2}{*}{ Water } \\
\hline & 2009 & 2010 & 2011 & 2012 & 2013 & & \\
\hline & $\mathrm{mm}$ & $\mathrm{mm}$ & $\mathrm{mm}$ & $\mathrm{mm}$ & $\mathrm{mm}$ & $\mathrm{mm}$ & $\%$ \\
\hline Precipitation & -803 & -720 & -662 & -848 & -750 & -757 & -71 \\
\hline Irrigation & -279 & -282 & -310 & -346 & -364 & -316 & -29 \\
\hline Snow storage change & -5 & -20 & -12 & -23 & -10 & -14 & -1 \\
\hline UZ-storage change & -7 & -26 & -0 & -17 & -8 & -14 & -1 \\
\hline ET & 770 & 854 & 777 & 845 & 860 & 821 & 77 \\
\hline OL-storage change & 61 & 0 & 15 & 61 & 30 & 33 & 3 \\
\hline OL-boundary outflow & 56 & 111 & 62 & 54 & 151 & 87 & 8 \\
\hline OL-flow to river & 66 & 91 & 50 & 59 & 118 & 77 & 7 \\
\hline SZ-storage change & 143 & -38 & 112 & 204 & -34 & 77 & 7 \\
\hline Total error & 2 & -30 & 22 & -11 & -7 & -5 & 0 \\
\hline Recharge & 143 & 105 & 218 & 204 & 171 & 168 & 16 \\
\hline
\end{tabular}


model was constructed with several assumptions when preparing the geospatial data set of unsaturated and saturated zones, and climate and land use parameters. This hydrological study of the CRB allows for the following main conclusions:

- MIKE SHE as a physical-based mathematical model uses a large number of hydrological parameters. All need to be adjusted to the climatic conditions of the study area to reach satisfactory results that correspond to reality.

- Evapotranspiration was found to be the main water loss factor among water balance components, with an average of $821 \mathrm{~mm} /$ year (77\% of the total water budget). As an arid land, AET is strongly dependent on irrigation water quantity irrespective of rainfall in downstream sites.

- AET is highly variable across the basin, with increases toward to downstream sites. The estimated AET in irrigation areas at downstream sites was almost two times higher than upstream sites. Therefore, decreased irrigation water causes increased aridity, particularly in downstream site.

- Estimated groundwater recharge varied between $180-221 \mathrm{~mm} /$ year, making up 17\% - 20\% of the total water budget. The highest groundwater recharge occurs from March to May with an average of $90-60 \mathrm{~mm} /$ month.

- The general direction of groundwater flow is toward the Syrdarya River. Base flow from basin boundary into the Syrdarya River was estimated at an average of $55 \mathrm{~mm} / \mathrm{year}$.

- The Chirchik River is gaining upper stream sites by overland flow on average $77 \mathrm{~mm} /$ year.

- The main water balance error was obtained from simulated overland flow. Adjusting the climate parameters of the model to the basin environment optimizes this. The overall water balance error is estimated $2.5 \%$ on average, which demonstrates that interacting hydrological components and parameters are well matched.

- Accurate irrigation schedule and operational information of hydro-engineering structures are critical model inputs in order to improve daily streamflow simulation and minimize numerical errors.

- This study confirms that in arid and semi-arid regions with intensive agricultural, integrated modelling is valuable for understanding water cycles in large basins.

The novelty of this study is a development of a local hydrological model for a relatively large river basin covering from upstream to downstream site of the basin and considering agricultural water use and administrative boundaries of the districts. This modeling approach is better describing formation, utilization and discharging of water resources under the impact of different land use process. This novel tool is urgent for integrated water resources management, particularly assessment of quantitative status of surface and groundwater resources. The comprehensive part of the research was the processing all required geospatial data (soil type, land use, topography, geology, river network geometry and agricultural water use) into integrated numerical model. This is challenging because all these data have never been used together before in hydrological studies in Chirchik River Basin. Using the model and model results, further steps of study should focus on predicting effects of climate and land use change to the hydrological regime of the CHRB. A part from quantitative analyses, in future research should also consider surface and groundwater quality issues.

\section{References}

[1] Saifulin, R., Russ, S., Fazylova, M., Fakhrutdinova, N. and Petrenko, Y. (1998) Management of Water Resources in Uzbekistan and Way of Raising Its Efficiency. Prepared for Central Asia Mission of United States. Agency for International Development. Institute for Strategic and Interregional Studies, Uzbekistan. http://pdf.usaid.gov/pdf docs/Pnacf072.pdf

[2] Strengthening Water Management and Transboundary Water Cooperation in Central Asia: Role of UNECE Environmental Conventions (2011) United Nations, Geneva.

[3] Deutsche Gesellschaftfür Internationale Zusammenarbeit (GIZ) (2013) Transboundary Water Management in Central Asia. https://www.giz.de/en/worldwide/15176.html

[4] Rakhmatullaev, S., Frederic, H., Kazbekov, J., Helene, C.J., Mikael, M.H., Le Coustumer, P. and Jumanov, J. (2013) Groundwater Resources of Uzbekistan: An Environmental and Operational Overview. https://cgspace.cgiar.org/handle/10568/40382

[5] Makhmudov, E., Rahimov, Sh., Chen, S. and Tzilili, A. (2013) Water Resources and Its Utilization in Uzbekistan. Pliograf Group Press, Tashkent, Uzbekistan.

[6] Dukhovny, V., Sorokin, A., Tuchin, A., Rysbekov, U., Stulina, G., Nerosin, S., Rusiev, I., Sorokin, D., Katz, A., Shahov, V. and Solodky, G. (2007) D 34-Final Report on Alternative Scenarios of Sustainable Development of Water 
Management for the Chirchik Basin. River Twin Project (2002-2006), Germany. http://cordis.europa.eu/publication/rcn/11810 en.html

[7] Iskandar, A., Fatima, N., Farida, A. and John, L. (2008) Socio-Technical Aspects of Water Management in Uzbekistan: Emerging Water Governance Issues at the Grass Root Level. Water \& Development Publications-Helsinki University of Technology, Helsinki. http://www.zef.de/module/register/media/b450 09 Central_Asian_Waters.pdf

[8] Kai, W. (2001) The Potentials for Success: Uzbek Local Water Management. Occasional Paper No. 29 Water Issues Study Group School of Oriental and African Studies (SOAS) University of London.

[9] Bahaa-Eldin, R., Ismail, Y., Azmi, J., Zainudin, O. and Azman, G. (2012) Application of MIKE SHE Modelling System to Set up a Detailed Water Balance Computation. Water and Environment, 26, 490-503. http://onlinelibrary.wiley.com/doi/10.1111/j.1747-6593.2012.00309.x/full http://dx.doi.org/10.1111/j.1747-6593.2012.00309.x

[10] Spyridon, P. and Fotios, M. (2015) Hydrological Simulation of Sperchios River Basin in Central Greece Using the MIKE SHE Model and Geographic Information Systems. Applied Water Science, 5, 1-9.

[11] Singh, R., Subramaniana, K. and Refsgaard, C. (1998) Hydrological Modelling of a Small Watershed Using MIKE SHE for Irrigation Planning. Agricultural Water Management, 41, 149-166. http://dx.doi.org/10.1016/S0378-3774(99)00022-0

[12] Foster, S. and Allen, D. (2015) Groundwater-Surface Water Interaction in a Mountain-to-Coast Watershed: Effects of Climate Change and Human stressors. Advances in Meteorology, 2015, Article ID: 861805. http://dx.doi.org/10.1155/2015/861805

[13] DHI, MIKE SHE User's Manual, Volume 1 and 2 (2012) An Integrated Hydrological Modelling Framework.

[14] Im, S., Kim, H. and Kim, C. (2008) Assessing the Impacts of Land Use Changes on Watershed Hydrology Using MIKE SHE. Environmental Geology, 57, 231-239. http://dx.doi.org/10.1007/s00254-008-1303-3

[15] Akram, F., Rasul, M.G., Khan, M.M.K. and Amir, M.S.I.I. (2012) A Comparative View of Groundwater Flow Simulation Using Two Modelling Software-MODFLOW and MIKE SHE. Proceedings of the 18th Australasian Fluid Mechanics Conference, Launceston, 3-7 December 2012, 811-815. http://toc.proceedings.com/17862webtoc.pdf

[16] Golmar, G., Shiv, P., Ali, M. and Ramesh, R. (2014) Evaluating Three Hydrological Distributed Watershed Models: MIKE-SHE, APEX, SWAT. Hydrology, 1, 20-39. http://dx.doi.org/10.3390/hydrology1010020

[17] Jiao, L., Tie, L. and Anming, B. (2016) Assessment of Different Modelling Studies on the Spatial Hydrological Process in an Arid Alpine Catchment. Water Resources Management, 30, 1757-1770. http://dx.doi.org/10.1007/s11269-016-1249-2

[18] Usmanov, S., Yasuhiro, M. and Tetsuya, K. (2015) Evaluation of Interpolation Methods for Spatial Modelling of Reference Evapotranspiration Using Modified Hargreaves Equation. Journal of Arid land Studies, 25, 141-144.

[19] Chanisheva, S. and Smirnova, E. (2011) Climate Characteristics of Tashkent Province. Uzhydrometeorological Bureau Press, Tashkent.

[20] Graham, D. and Butt, M. (2005) Watershed Models: Flexible Integrated Watershed Modelling with MIKE SHE. Taylor and Francis Group Press, Boca Raton.

[21] Allen, R., Pereira, S., Reas, D. and Smith, M. (1998) Crop Evapotranspiration. FAO Irrigation and Drainage Paper 56, Rome, 300.

[22] Nash, J. and Sutcliffe, J. (1970) River Flow Forecasting through Conceptual Models. Journal of Hydrology, 10, 282290. http://dx.doi.org/10.1016/0022-1694(70)90255-6 


\section{Submit or recommend next manuscript to SCIRP and we will provide best service for you:}

Accepting pre-submission inquiries through Email, Facebook, Linkedin, Twitter, etc A wide selection of journals (inclusive of 9 subjects, more than 200 journals)

Providing a 24-hour high-quality service

User-friendly online submission system

Fair and swift peer-review system

Efficient typesetting and proofreading procedure

Display of the result of downloads and visits, as well as the number of cited articles

Maximum dissemination of your research work

Submit your manuscript at: http://papersubmission.scirp.org/ 